must be satisfied before dealing with the phase of maximum ionisation: he expresses the terms as a function of the variation of temperature and of the variation of magnitude.

RoMe

Royal National Academy of the Lincei, Feb. 18. F. ENRIQUES: Elliptical surfaces of zero genus. P. Burgatti : Displacement of the perihelion in the theory of relativity. G. BRUNI and G. NATTA: Structure of guttapercha, studied by electron rays. By the action of electron rays, crystalline or $\alpha$-guttapercha is rapidly transformed into the amorphous $\beta$-form. The $\alpha$-variety has rhombic or pseudorhombic structure, with the axial ratios $1: 1 \cdot 176: 1 \cdot 47$. On the assumption that unit cell contains four isoprene groups, the calculated density is 0.94 , which agrees well with the most recent experimental data. A. ROSENBLATT : Non-linear $m$-harmonic equations with two independent variables. (1) Green's $m$-harmonic function in the case of the circle. M. GHERMANESCO : Trigonometric sums of Alaci. R. EnNAUdI : Propagation of superficial elastic waves. D. GraffI : The eccentricity of the orbit in the problem of two bodies of variable mass. D. C. LEwIS, JR. : Periodic oscillations of a dynamic system. L. SonA : Translocirculatory current investing a bilateral lamina. L. SolarnI : A particular case of the problem of the vertex of a pyramid. A. Missirour and A. Corraderti : The possibility of the phenomena of hybridism in malarigenic parasites. G. Craccio : Regeneration of the crystalline in examples of various ages of Salamandra maculosa and regeneration of the crystalline in transplanted eyes of Triton cristatus. G. BRUNELLI and G. BINI: The emigration of a species of Teuthis from the Red Sea to the Aggean Sea.

\section{Official Publications Received}

Great BRITAIN AND IRELAND

Experimental and Research Station, Nursery and Market Garden Industries' Development Society, Ltd., Turner's Hill, Cheshunt, Industries' Development Society, Ltd., Turner's Hill, Cheshunt, Herts. Nineteenth Annual Report, 1933. Pp. 115 . (Cheshunt.) Education (Scotland) Report for the Year 1933 by the Director
on the Royal Scottish Museum, Edinburgh. Pp. 13. (Edinburgh.) on the Royal Scottish Museum, Edinburgh. Pp. 13. (Edinburgh.) British Empire Cancer Campaign. Eleventh Annual Report of the
Grand Council presented at the Meeting held at the House of Lords, Grand Council presented at the Meeting held at the House of Lords, -7-34. Pp. xxiii +220. (London: British Empire Cancer Campaign.) Imperial Agricultural Bureaux. Fourth Annual Report of the
Executive Council, 1932-1933. Pp. 23. (London: H.M. Stationery Executive Coun
Office.) 18. net.

Transactions of the Institution of Chemical Engineers. Vol. 11, 1933. Pp. 227. (London: Institution of Chemical Fngineers.) Ministry of Agriculture and Fisheries. The Agricultural Output of England and Wales, 1930-1931: Report on certain Statistical Enquiries relating to the Output of Agricultural Produce and to the Agricultural Industry in general, together with Results of Earlier
Enquiries of a similar Nature. (Cmd. 4605.)
$\mathbf{P p}$. 67. (London: H.M. Stationery Office.) 18. net.

Falmouth Observatory. Report of the Joint Observatory Committee to the Royal Cornwall Polytechnic Society and to the Falmouth Town Council for the Year 1933. Pp. 3. Meteorological Notes and Tables for the Year 1933, also Additional Meteorological Tables of Temperature, Rainfall and of Sunshine, 1880-1933, and Miscellaneous Phenomena during 1933. Pp. 11. (Falmouth.)

University of Bristol. The Annual Report of the Agricultural and Horticultural Research Station (The National Fruit and Cider Institute), Long Ashton, Bristol, 1933. Pp. $214+7$ plates. (Bristol.)

The Scientific Proceedings of the Royal Dublin Society. Vol. 21 (N.S.), No. 7: Report of the Irish Radiun Committee for the Year 1933 ; including Reports by Oliver Chance, Dr. W. G. Harvey, W. J. MacHugh and Oswald J. Murphy. Pp. 59-66. (Dublin: Hodges, Figgis and Co.; London: Williams and Norgate, Ltd.) $6 d$

Air Ministry: Aeronautical Research Committee: Reports and Memoranda. No. 1576 (Spin. 107, 138) : Spinning of Pterodactyl Mark IV. Part 1, by A. V. Stephens and J. Cohen ; Part 2, by A. V.
Stephens. Pp. $10+2$ plates. (London: H.M. Stationery Office.) 9d. net.

Amgueddfa Genedlæthol Cymru : National Museum of Wales. National Tronal Hal of the University of Wales.) 58 .

\section{Othrar CoUntrites}

Bernice B. Bishop Museum. Bulletin 115 : Archæology of Kahoolawe. By J. Gilbert McAllister. Pp. $61+5$ plates. Bulletin 116 Stone Remains in the Society Islands. By Kenneth P. Emory. Pp. $182+20$ plates. Bulletin 117 : Astelia and Pipturus of Hawail. By Carl Skottsberg. Pp. $77+38$ plates. Bulletin 118 : Tuamotuan Stone Structures. By Kenneth P. Emory. Pp. $78+10$ plates. Bulletin 119 by Arthur A. Pegau; Smaller Foraminifera, by Joseph A. Cushman Larger Foraminifera, by G. Leslie Whipple ; Corals, by J. Edward Hoffmeister; Smaller Echinoids, by H. L. Hawkins : Decapod Crustaceans, by Mary J. Rathbun. Pp. $263+44$ plates. Bulletin 120 The Flora of Makatea. By Gerrit Parmile Wilder. Pp. $49+5$ plates. Bulletin 121 Some Hawaiian Oribatoidea (Acarina). By Arthur Paul Jacot. Pp. $99+16$ plates, Bulletin 122 : Mangaian Society. By Te Rangi Hiroa (P. H. Buck). Pp. 207. Bulletin 124: Report of th Director for 1933. By Herbert E. Gregory. Pp. 44. (Honolulu.)

Report of the Aeronautical Research Institute, Tokyo Imperial University. No. 106: On the Uplift acting upon a Heated Fibre vertically suspended in Gas. By Yositada Takenouti. Pp. 337-384. (Tôkyô: Koseikai Publishing House.) 40 sen.

Journal of the Faculty of Agriculture, Hokkaido Imperial University. Vol. 26, Part 4: Flora of Hokkaido and Saghalien. 4: Kingo Miyabe and Yushun Kudo. Pp. 389-528. (Tokyo: Maruzen

Co., Ltd.) Study of the Behavior and Social Relations of Howling Monkeys. By C. R. Carpenter. (Comparative Psychology Monographs, Vol. 10, No. 2.) Pp.

Meddelanden frản Statens Skogsforsoksanstalt. Häte 27, 1932-34. Pp. $\mathbf{v}+379$. (Experimentalfăltet.)

Svenska Linne-Sallskapets Årsskrift. Årgång 17, 1934. Pp. xii + 151. (Uppsala.)

Kungl. Svenska Vetenskapsakademiens Handlingar. Serien 3, Band 13, No. 3: Northern and Arctic Invertebrates in the Collection of the Swedish State Museum. 12: unicata, 4: Cionidæ, Ascidiidæ, Agnesiidæ, Rhodosomatidæ. By Dr. Augusta Arnbăck-Christie-Linde. Pp. 91+6 plates. Serien 3, Band 13, No. 4: Systematische und biologische Studien über die Termiten Javas und Celebes'. Von N. A. Kemner. Pp. $241+22$ plates. Serien 3, Band 13, No. $5:$ On the Heads of certain Arthrodires. 1: Pholidosteus, Leiosteus and Acanthaspids. By Erik A:son Stensiö. Pp. $79+14$ plates. Serien 3 , Band 13, No. 6 : Catalogue of Auroræ boreales observed in Northern Sweden during the Time August 1932-March 1933. By Axel Corlin. Pp. 51. (Stockholm: Almquist and Wiksells Boktryckeri A.-B.

Paleontologiese Navorsing van die Nasionale Museum, Bloem. fontein. Deel 2 , Stuk 6 : Oor die Indeling van die Dicynodontidæ Pp. 67-101. (Bloemfontein.)

Science Reports of the Tokyo Bunrika Daigaku, Section B. No. 19 Sur une nouvelle espèce du genre Paracercorchis (Trematode) parasite Ogata. Pp. 203-211. 15 sen. No. 20: Telorchis konoi n.sp. (TreOgata. Pp. 203-211. 15 sen. No. 20: Telorchis konoi n.sp. (TreTóji Ogata. Pp. 213-219. 15 sen. No. 21 : Weiteres uber den isoelektrischen Punkt der Bakterien. Von $G$. Yamaha und $S$. Abe. Pp. 221-229. 15 sen. No. 22: On the Range of Lethal Body Temperature of the Rat. By Nobumasa Yagi and Jukich Shimoizumi. Pp. 231-242. 20 sen. No. 23: tber die Bildung der Urease bei Aspergillus niger. Von Tomoo Miwa und Seiichiro Yoshii. Pp. 243-270. 30 sen. No. 24: Contribution to the Study of Japanese Arenicola. Part 1: Notes 24: Contribution to the Study of Japanese Arenicola. Part 1: Notes on the Habits and Distribution of Arenicola in Japan. By Keizo Takahashi. Pp. 271-279. 20 sen. (Tokyo: Maruzen Co., Ltd.) Publications of the Washburn Observatory of the University of
Wisconsin. Vol. 15, Part 5: Space Reddening in the Galaxy from the Wisconsin. Vol. 15, Part 5: Space Reddening in the Galaxy from the Colours of 733 B-Stars.

The Comparative Anatomy of Extra-Chromosomal Types in Datura The Comparative Anatomy of Extra-Chromosomal Types in Datura stramonium. By Edmund W. Sinnott, Helen Houghtaling and Albert F. Blakeslee. (Publication No. 451.)

ington, D.C. : Carnegie Institution.) Vol. 23, No. 2: containing the Twenty-third Annual Report of the Brooklyn Botanic Garden, 1933 Pp. 170. (Brooklyn, N.Y.)

Proceedings of the Academy of Natural Sciences of Philadelphia, Vol. 86. Description of New Birds from Peru, with Notes on the Nomenclature and Status of other little-known Species. By M. A Carriker, Jr. Pp. 317-334. Zoological Results of the Third De Schaunsee Fowler. Pp. 335-352. (Philadelphia.)

Field Museum of Natural History. Zoology Leaflet 13: Sculptures by Herbert Haseltine of Champion Domestic Animals of Great Britain Pp. 45. (Chicago.) 25 cents.

Statens Meteorologisk Hydrograflska Anstalt. Årsbok, 13, 1931. vii. Meteorologiska iakttagelser i Riksgrånsen. Pp. ii $+49.4 .00 \mathrm{kr}$ Arsbok, 14, 1932. vi. Aerologiska iakttagelser i Sverige. Pp. 15 $3.00 \mathrm{kr}$. Ársbok, 15, 1933 . I. Månadsöversikt over vaderlek och vattentillgång jämte anstaltens a rsberättelse. Pp. 90. 2.50 kr. Arsbok 15, 1933. ii. Nederborden i Sverige. Pp. $56.2 .50 \mathrm{kr}$. (Stockholm. Functions and Organisation of the India Meteorological Department, 1934. Pp. 23. (Simla: Government of India Press.)

Catalogues

A Catalogue of Books and Periodicals on Botany. (No. 492.) Pp. 38. London: Bernard Quaritch, Ltd.

Chance-Parsons Optical Glass. Pp. 18. (Birmingham: Chance Brothers and Co., Ltd.

The Finch Electron-Diffraction Camera. Pp. 10. (London: Adam

Hilger, Ltd.) Thermometers, Hygrometers, Pressure Gauges. (List

No. 586.) Pp. 60. (London: C. F. Casella and Co., Ltd.) 